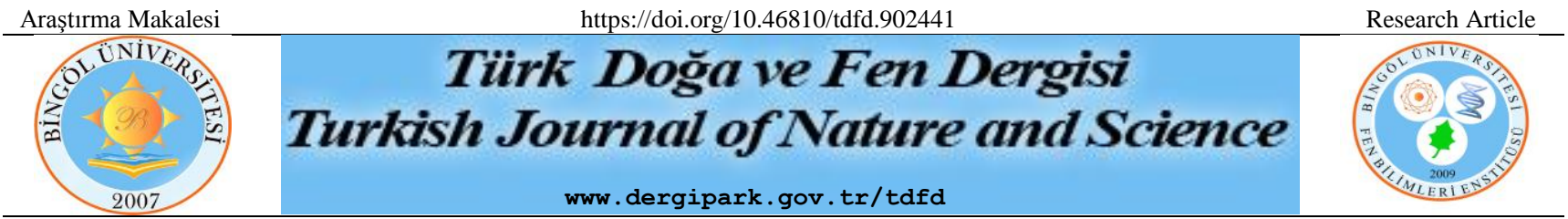

\title{
Rapid Characterization of Cell and Bacteria Counts using Computer Vision
}

\author{
Fatih AKKOYUN ${ }^{1}$, Adem ÖZÇELİ ${ }^{1 *}$ \\ ${ }^{1}$ Aydın Adnan Menderes Üniversitesi, Mühendislik Fakültesi, Makine Mühendisliği Bölümü, Aydın, Türkiye \\ Fatih AKKOYUN ORCID No: 00000-0002-1432-8926 \\ Adem ÖZÇELIKK ORCID No: 0000-0002-3124-795X \\ *Sorumlu yazar: aozcelik@adu.edu.tr
}

(Alınış: 24.03.2021, Kabul: 11.05.2021, Online Yayınlanma: 25.06.2021)

\section{Keywords Mechanical engineering, OpenCV, Machine vision, Cell counting}

\begin{abstract}
The cell counting process is an important procedure for various cell and cell-related research applications. Many life science-related studies examine the cells to compare results concerning cell numbers and variations. Most of the related studies are conducted using manual counting methods. However, manual counting is difficult, time-consuming, and fallible. This study proposes an automated cell counting software using computer vision (CV) technology and experimental investigation for automated cell and bacterium counting. The software processes images for calculating cell/bacterium count, concerning pre-defined user parameters. In the experiments, cell and bacteria calculations are tested for single and mixed variations. Experimental results are examined by comparing manual and automated cell counting results. The accuracy of the software is found for calculating the cell count of a single and mixed cell/bacteria solution to be 99\% and 98\%, respectively. Also, the software can process video and camera streams in real-time. The computerized method is a good alternative due to providing accurate results and minimizing user-related errors. open-sourced CV software can be used in biomedical and fundamental biological research studies for rapidly determining target cell numbers.
\end{abstract}

\section{Bilgisayarıı Görüş Kullanarak Bakteri ve Hücre Sayılarının Hızlı Karakterizasyonu}

\begin{abstract}
Anahtar
Kelimeler

Makine

mühendisliği,

OpenCV,

Makine

görüşü,

Hücre sayımı

Öz: Hücre sayım işlemi, çeşitli hücre ve hücreler ile ilişkili araştırma uygulamalarında kullanılan önemli bir prosedürdür. Fen bilimleri alanında çoğu araştırmada hücreler incelenirken, hücre sayısı ve ilgili hesaplamalar ile sonuçların karşılaştırılması yapılmaktadır. Bu alandaki çalışmalarda yaygın olarak manuel olarak sayım yöntemi kullanılmaktadır. Ancak manuel sayım zaman alıcı, zorlu ve hataya meyilli bir ölçüm yöntemidir. Bu çalışmada, bilgisayarlı görüş (CV) teknolojisi kullanan otomatik hücre sayım yazılımı sunulmaktadır. Hücre ile bakteri örneklerinin otomatik sayımı deneysel çalışma yapılarak test edilmiş ve deneysel sonuçlar, manuel ve otomatik hücre sayımı yöntemlerinden elde edilen sonuçların karşılaştırılmasıyla incelenmiştir. Geliştirilmiş olan yazılım önceden tanımlanmış kullanıcı değişkenleri doğrultusunda, görüntüleri hücre/bakteri sayısını hesaplamak için incelemektedir. Yazılımın, tek türde hücre/bakteri için \%99 ve karışık hücre/bakterilerde \%98 sayım doğruluğuna ulaştığı görülmüştür. Buna ek olarak, aynı yazılım ile, video ve gerçek zamanlı kamera görüntüleri de aynı amaçla işlenebilmektedir. Bu çalışmada önerilmiş olan açık kaynak kodlu CV yazılımı, birçok araştırmacı tarafından, birçok araştırmada, otomatik olarak hücre sayımının yapılmasında kullanılabilecektir.
\end{abstract}

analyses, the determination of viable and non-viable cell

\section{INTRODUCTION}

Quantification of cells and bacteria is an important step in biomedical research [1,2]. For example, concentrations of different bacteria samples are essential for pathogen diagnostics, environmental biofilm characterization, and bioreactor process optimization $[3,4]$. Especially in cell culture processes and cell numbers is required for better characterizing the experimental conditions, and optimization of the cell culturing protocols [5,6]. Considering the shape complexity and heterogeneity of mixed sample solutions including cells and bacteria, accurate, rapid, and practical quantification of targeted cells and bacteria under optical microscopy is a valuable capability for fundamental research. 
There are three general approaches to cell and bacteria counting. The first one is to use standard manual hemocytometers to count cells under an optical microscope [7]. In this approach, a special microscope slide with known grid dimensions and depth information is used to sample a cell solution which is usually diluted a factor of times. By counting the number of cells inside a reference grid within the fixed volume of the grid, the total number of cells in the initial solution is calculated. This method is labor-intensive as it relies on the counting of the cells manually by a user which can be a time-consuming process for quantification of a large number of samples. The second approach for cell and bacteria enumeration is to use automated cell counters which are commercially available from various companies [8]. Even though these commercial instruments make the cell counting very practical, they are commonly available to well-funded central labs due to their relatively higher costs compared to hemocytometers. The third approach is to use flow cytometers to count cells and bacteria [9]. Flow cytometer equipment is well-known for very high accuracies and abilities to count cells with different characteristics in a continuous manner. However, because of their extremely high costs and maintenance requirements, flow cytometers are only available in distinguished research facilities. There are also few open-sourced approaches [9] to counting cells using computer vision including ImageJ which is initially developed by the National Institute of Health of the United States of America [10]. ImageJ is free-to-use software that can be applied to count cells from a still image. However, the tools and settings of the general plugins can be limited and not suitable for cases that may require more than one threshold for counting mixed samples in the same image. In the low-resource-setting laboratories, standard hemocytometers are the only choice for quantification of cells and bacteria. Therefore, there is a need for an open-sourced, easy-to-use, practical, automated, and accurate method for counting cells and bacteria.

Image processing and target object/feature detection are increasingly becoming more practical with the advancement of computational hardware and software $[11,12]$. In this work, an open-sourced automated cell and bacteria counting method based on computer vision $(\mathrm{CV})$ is demonstrated. Single-layer of cell/bacteria solutions on glass slides are imaged under an ordinary bright-field optical microscope, and the still images are processed using $\mathrm{C}++$ programming language and opensourced computer library (Open CV). This method is successfully applied in simple and complex situations where cells and bacteria are mixed. Furthermore, viable and non-viable yeast cells are counted after staining the non-viable cells with methylene blue. The method presented here is tested to be a capable and reliable approach for precisely counting target samples, and can be used for cell and bacteria quantification in biomedical research.

\section{MATERIALS and METHODS}

A cell and bacteria counter software, which automatically calculates total cells/bacteria number is demonstrated. The developed software is designed to process images for counting cells using detected pixel count and a reference object area in pixel concerning predefined user parameters. The cell counting software has inputs including an image, a reference cell area in pixel, Hue Saturation Value (HSV) threshold, and BlackWhite (BW) threshold parameters. The output of the software is the counted cell numbers. A block diagram of the software is shown in Figure 1.

The cell counting process starts with image input. Initially, a color image is acquired by the software. In the second stage, a threshold is applied to the image concerning pre-defined HSV parameters, and new parameter values are also accepted via the Graphical User Interface (GUI) before processing the image. In the next stage, the thresholded color image is converted to the BW image. Then, Gaussian and blur filter is applied before finding the contours of the image. A second threshold is applied to the image for eliminating the background and separating the cells in the processed image. Detected contours are considered as an array and indices which include the area in pixel and the total contour number. Each contour represents a detected cell in this stage. A pre-defined user parameter is applied to calculate the total count of the cells which is an averaged area value of the target cells or bacteria in pixels. The detected total contour area is divided into the averaged area to obtain cell counting results. The flowchart of this solution is shown in Figure 2.

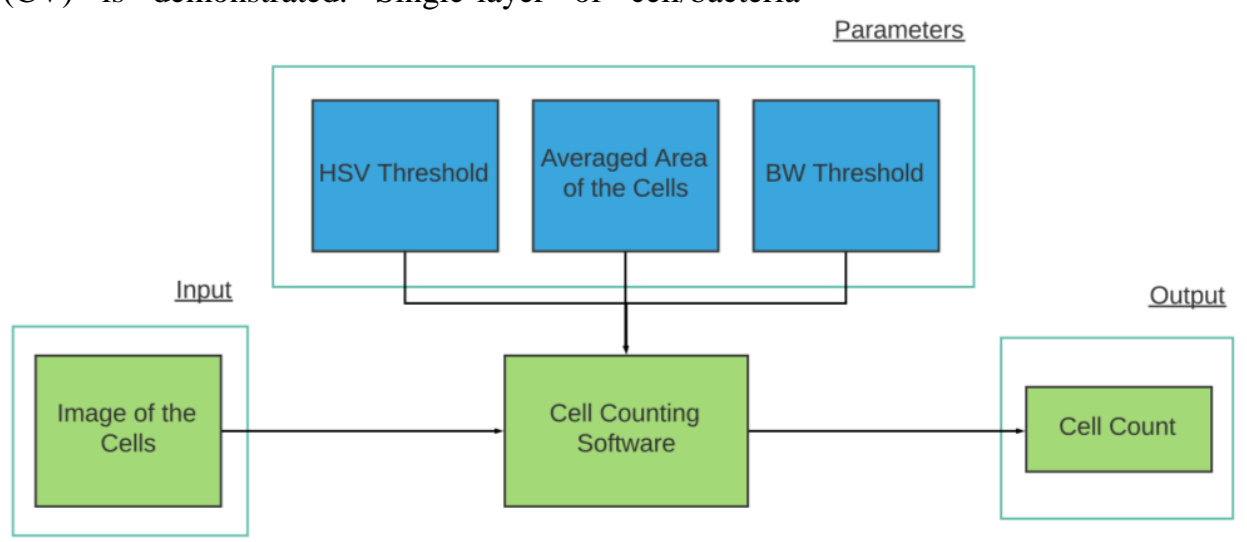

Figure 1. The block diagram of the cell counting process shows the input, pre-defined user parameters, and output 


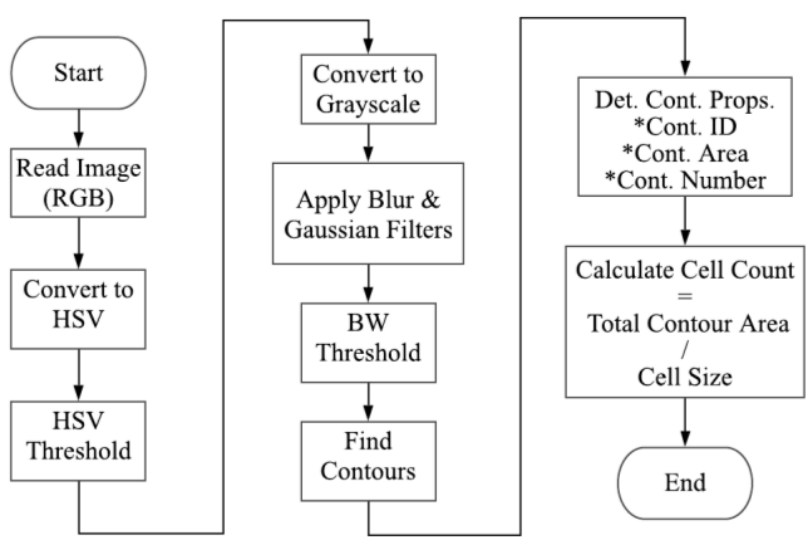

Figure 2. The flowchart of the cell counting process is given for illustration

Bacteria samples are prepared from Enterococcus faecium (E. faecium) which is a type of Gram-positive lactic acid bacteria. To prepare the bacteria suspension samples, the starter bacteria are kept in the nutrient broth overnight at $37{ }^{\circ} \mathrm{C}$. Then, the bacteria cultures are washed and span at 5000 RPM for 5 minutes in centrifuge followed by a phosphide buffer saline (PBS) wash. Finally, the washed bacteria sample is resuspended in PBS to be used in the experiments. In the cell experiments, yeast cells called Saccharomyces cerevisiae which are eukaryotic cells are prepared in a liquid suspension. For this, commercially available yeast cells are acquired and kept in warm water at around 30 ${ }^{\circ} \mathrm{C}$ for around 2 hours to activate the yeast cells. To prepare the dead yeast cells for viable-nonviable cell counting experiments, some of the yeast cell solutions are exposed to $>70{ }^{\circ} \mathrm{C}$ for 5 minutes. Then, dead yeast cells are stained by using a $0.01 \%$ methylene blue solution and incubated for about 5 minutes. After this, the stained cells are washed and re-suspended in deionized water. A mixture of live and dead cells is imaged for counting the viable and nonviable cells. Delivery of the cell solutions is achieved via a homebuilt syringe pump [13]. An inverted optical microscope (OX.2053-PLPH, Euromex, Netherlands) is used to acquire the still images of bacteria, the cell-bacteria mixture, and the viable and non-viable yeast cell solution. For the image collection, a 40x objective lens of the microscope is applied, and an HD-colored camera (HD- Ultra, Euromex, Netherlands) is used.

\section{RESULTS and DISCUSSION}

All the images are captured using the microscope camera with maximum of $6 \mathrm{MP}$ resolution. Each image that is captured from the field of view of the microscope is recorded under the identical illuminated environment with a 40X objective lens. Bacterium, yeast cell, live, and dead cells in various combinations are counted using the software, and the results of the experiments are analyzed. As a test of the automated counting algorithm used in the software, spherical polystyrene particles with a diameter of $5 \mu \mathrm{m}$ are used in suspensions from low (Figure $3 \mathrm{a}$ and $\mathrm{b}$ ) to high concentrations (Figure 3c and d). For the lowest concentration, the actual and automatically counted numbers are found to be the same. For the highest concentration, a difference of $0.35 \%$ is the result of the actual value and average of counted values.
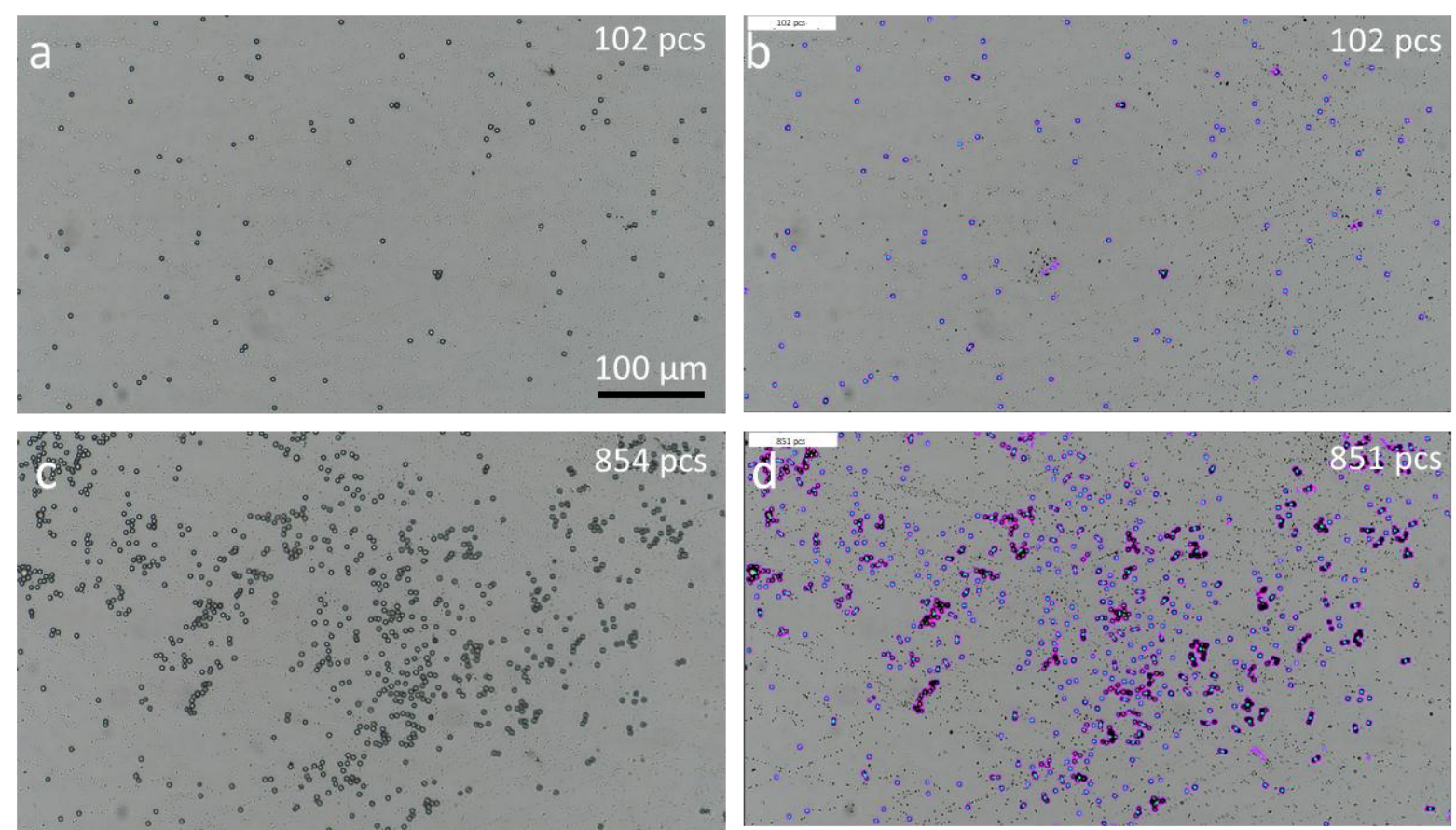

Figure 3. Manuel and automated particle counting for testing the software. a. low concentration of the polymer particles, b. automated counting of the lowest concentration sample, c. the highest concentration sample, and d. automated counting of the highest concentration sample 


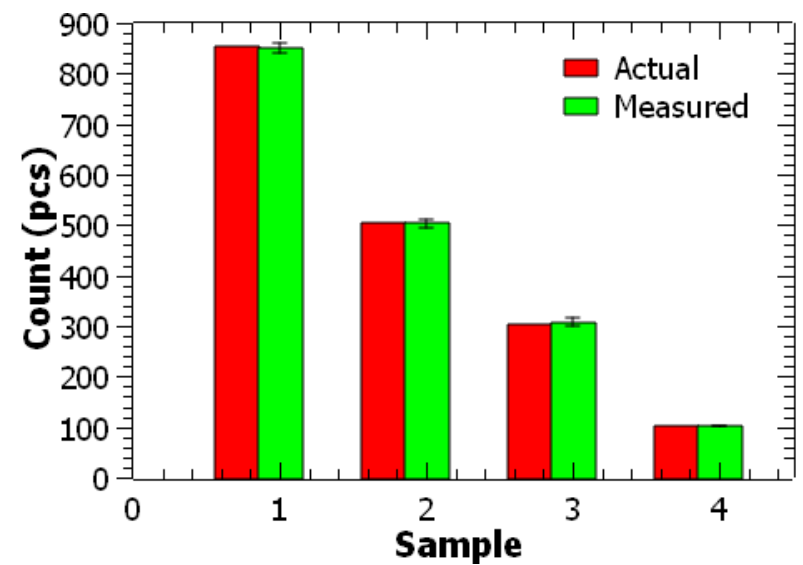

Figure 4. Actual and measured polymer particle numbers for 4 different concentrations are given. Error bars are generated from the standard deviation of 10 measurements

These images that are collected from increasingly more concentrated samples are measured both manually via manual cell counter plugin of ImageJ and automatically using the automated cell counting CV software. The manual cell counting plugin of the ImageJ allows individual marking and recording of different types of objects. This is a labor-intensive process that requires constant user input. The manual counting process is repeated at least three times for each image, and the average of these measurements is used as the actual numbers of the particles/cells/bacteria shown in an image. The error between these manual counts is found to be smaller than $1 \%$. Initial testing experiments are conducted with the calibration suspensions of $5 \mu \mathrm{m}$ polystyrene particles with four different samples with increasingly higher concentrations. These solutions are sampled after thoroughly aspirating the suspensions in Eppendorf tubes to avoid particle sedimentation. The numbers of actual and automated counts for the different concentrations are shown in Figure 4.
In Figure 5, a mixture of E. faecium bacteria and the yeast cells are imaged for automatically counting both bacteria and cells from the same sample. In the image processing for analysis of certain objects, the general process is to adjust and set a threshold value. However, this only shows the results of above or below the threshold value. For counting different objects in the image, additional operations are necessary, such as processing the same image with another filtering, cropping, and thresholding steps. In this study, for counting bacteria and cells in an image, multiple filters and multiple threshold operations are processed automatically. For this, different thresholds are applied for different-sized populations to obtain the numbers of smaller bacteria and larger cells as accurately as possible. For the yeast cell and bacterium concentration, the actual and automatically counted numbers are found to be very close due to the circular shape and high reflectance of the yeast cells under illumination. The software perfectly detected all yeast and the accuracy for the bacteria counting process was above 0.98 .

In Figure 6, actual and measured bacterium and cell counts are given for comparison. The averaged measured bacteria number shows a deviation of $1.7 \%$ from the actual bacteria count. Measured and actual cell counts show no deviation. The deviation observed in the bacteria counting is most likely due to the chain-forming nature of the bacteria which poses an additional challenge in precisely counting bacteria. For the viable and non-viable cell concentration, the actual and automatically counted numbers are found to be close. The accuracy of automated cell counting software was found to be $96 \%$ and $95 \%$ for viable and non-viable cells, respectively.
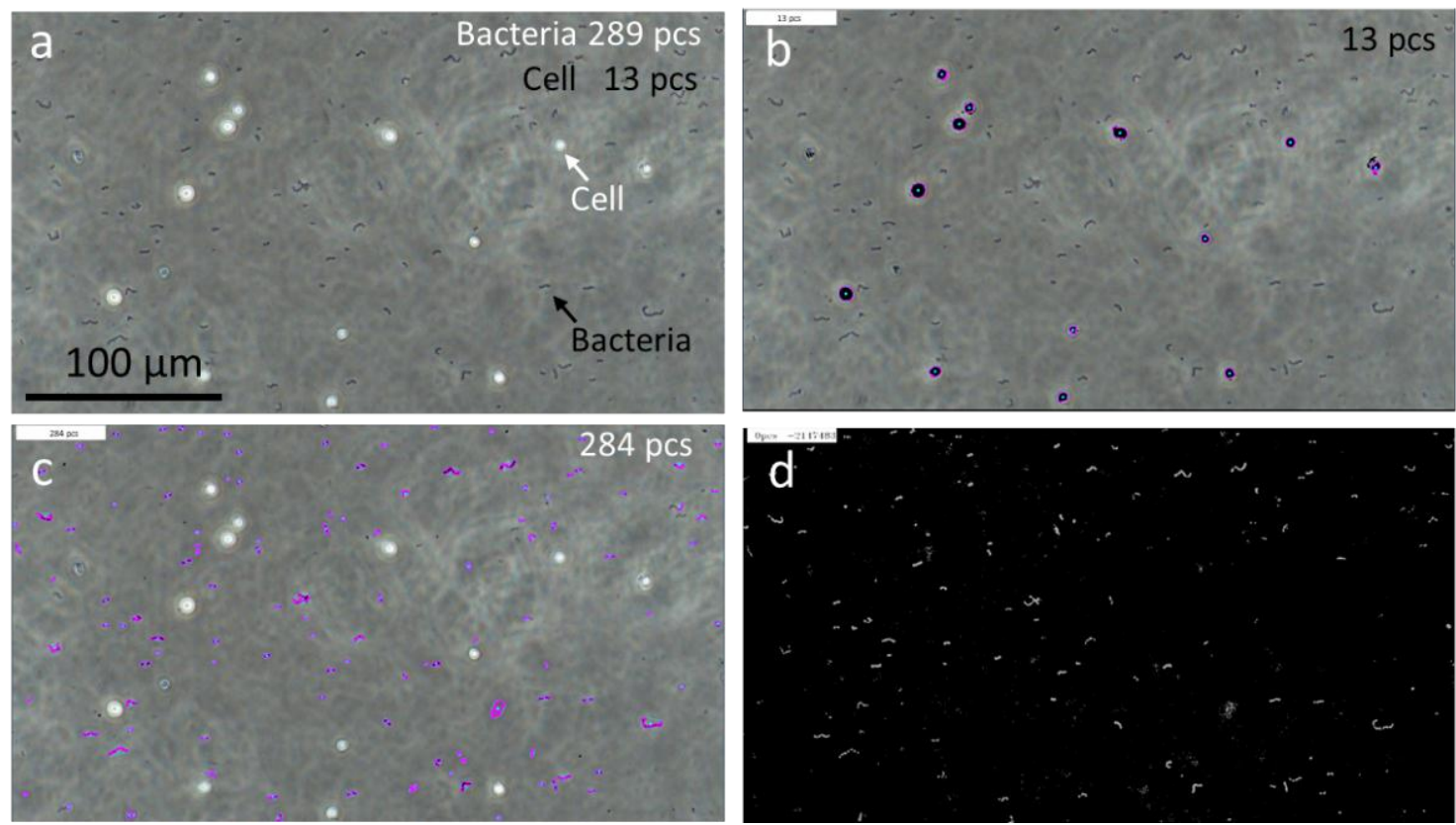

Figure 5. Mixed cell/bacterium counting. a. yeast cell and bacteria concentration, b. detected and counted yeast cells in the concentration, c. detected and counted bacteria in the concentration, and d. thresholded image with detected only bacteria 


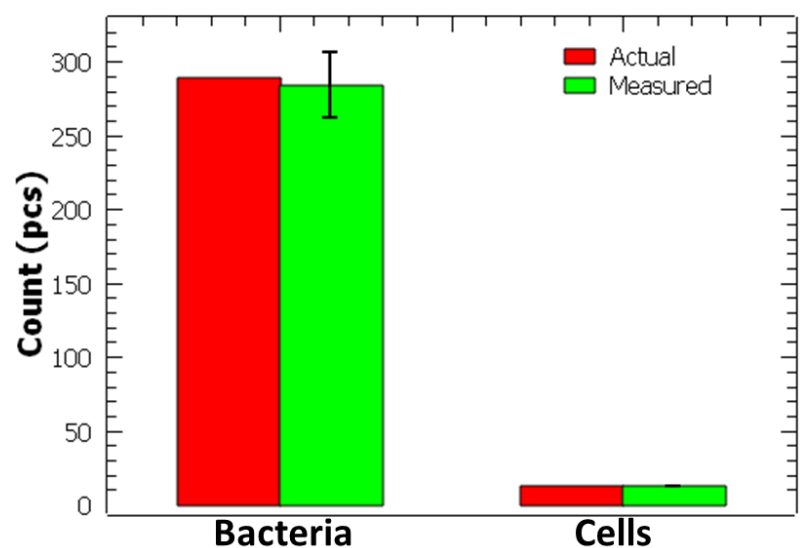

Figure 6. Actual and measured bacteria and yeast cell numbers are given. Error bars are generated from the standard deviation of 10 measurements

In Figure 7, a mixed population of dead and live cells is automatically counted. The stained dead (non-viable) cells appear as blue colored. In the counting viable and non-viable cell counting process, the acquired image is thresholded using HSV values and filtered with blurring. Then, the image is converted and filtered using the BW thresholding operation. After this, these two operations are recycled for counting viable and non-viable cells. As shown in Figure 8, the average number of measured nonviable cells deviates from the actual number is $4 \%$, and the automatically counted viable cell number deviates from the actual count by $4.9 \%$. These deviations are both less than $5 \%$ and account for reasonable accuracy of the automated cell counting. A possible explanation for higher than previous deviations that are observed in the bacteria and cell counting is the variation of the staining contract among non-viable cells and also their size irregularities appearing after the induced cell death process.

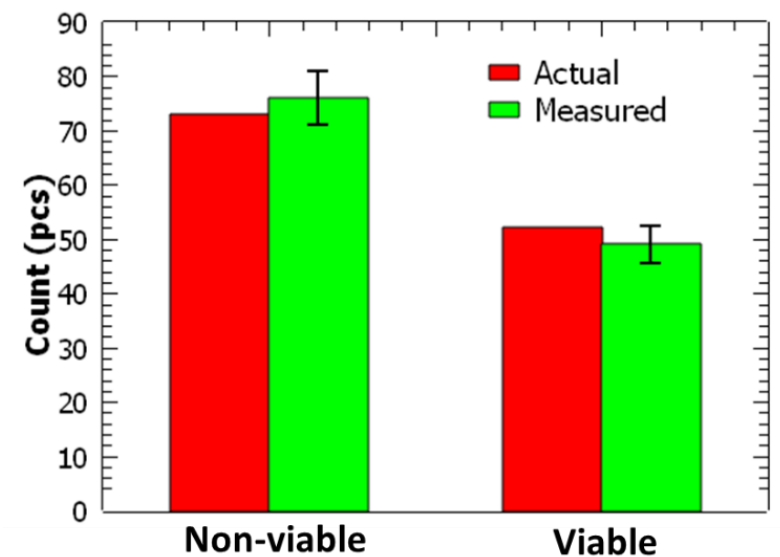

Figure 8. Actual and measured non-viable and viable yeast cell numbers are given. Error bars are generated from the standard deviation of 10 measurements
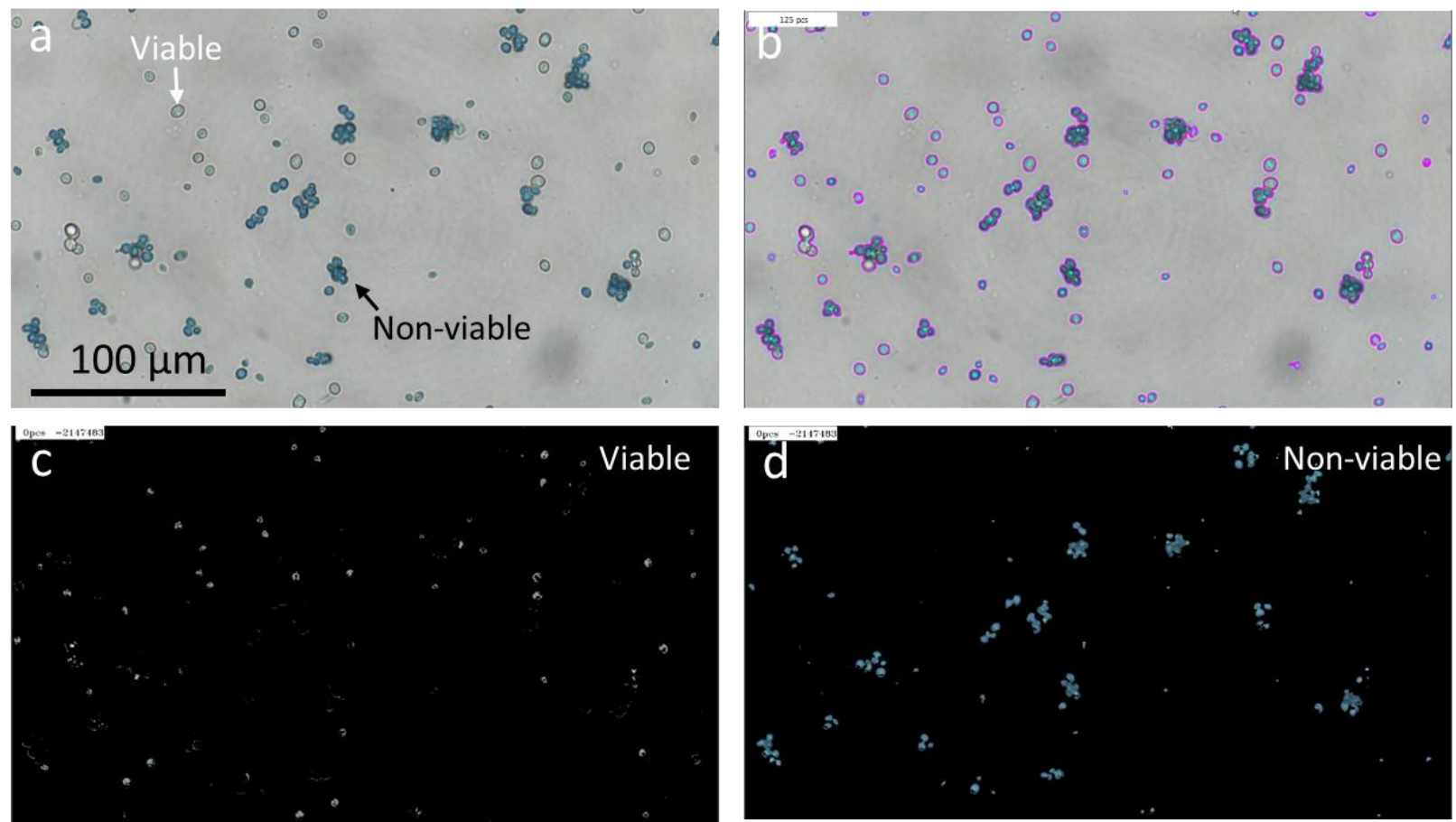

Figure 7. Mixed viable/non-viable cell counting. a. viable and non-viable yeast cell concentration, b. detected and counted viable cells in the concentration, c. thresholded image with only viable cells, and d. thresholded image with only non-viable cells. 


\section{CONCLUSION}

Herein, an automated cell and bacteria counting method is demonstrated using OpenCV computer software. This software takes image inputs and calculates cell counts by applying thresholding and contouring processes on target cells. The software processes input images to detect the target object concerning the predetermined user parameters. The cell properties in pixels are calculated as output by evaluating the contour properties of the cells in the images. This method is successfully applied in counting microparticles, bacteria, and cells for simple low concentration samples and more complicated mixed and high concentration samples. Besides, viable and non-viable yeast cells are counted with less than 5\% deviations from the actual numbers. The findings of this work indicate an accurate counting of mixed samples. This approach applied in this work can also be extended to counting different cell types in a flow-through setting using a high frame rate camera and image grabber hardware. Rapidly counting viable and non-viable cells is a valuable capability in fundamental research. The method demonstrated here presents a simple and opensourced alternative to manual cell and bacteria counting for biomedical researchers.

\section{ACKNOWLEDGMENT}

The authors thank Mustafa Duran for fruitful discussions of the experimental design. This research was supported by Aydın Adnan Menderes University Research Fund. Project Number: MF-20002.

\section{REFERENCES}

[1] Ongena K, Das C, Smith JL, Gil S, Johnston G. Determining cell number during cell culture using the Scepter cell counter. J. Vis. Exp. 2010;45:2204.

[2] O'Brien J, Hayder H, Peng C. Automated Quantification and Analysis of Cell Counting Procedures Using ImageJ Plugins. J. Vis. Exp. 2016;117:54719.
[3] Brown MR, Hands CL, Coello-Garcia T, Sani BS, Ott AIG, Smith SJ, et al. A flow cytometry method for bacterial quantification and biomass estimates in activated sludge. J. Microbiol. Methods. 2019;160:73-83.

[4] Ricchi M, Bertasio C, Boniotti MB, Vicari N, Russo S, Tilola M, et al. Comparison among the Quantification of Bacterial Pathogens by qPCR, dPCR, and Cultural Methods. Front. Microbiol. $2017 ; 8$.

[5] Cadena-Herrera D, Esparza-De Lara JE, RamírezIbañez ND, López-Morales CA, Pérez NO, FloresOrtiz LF, et al. Validation of three viable-cell counting methods: Manual, semi-automated, and automated. Biotechnol. Reports. 2015;7:9-16.

[6] Piccinini F, Tesei A, Arienti C, Bevilacqua A. Cell Counting and Viability Assessment of 2D and 3D Cell Cultures: Expected Reliability of the Trypan Blue Assay. Biol. Proced. Online. 2017;19.

[7] Freund M, Carol B. Factors Affecting Haemocytometer Counts Of Sperm Concentration In Human Semen. Reproduction. 1964;8:149-155.

[8] Green R, Wachsmann-Hogiu S. Development, History, and Future of Automated Cell Counters. Clin. Lab. Med. 2015;35:1-10.

[9] McKinnon KM. Flow Cytometry: An Overview. Curr. Protoc. Immunol. 2018;120.

[10] Schneider CA, Rasband WS, Eliceiri KW. NIH Image to ImageJ: 25 years of image analysis. Nat. Methods. 2012;9(7):671-5.

[11] Onat C, Daskin M, Toraman S, Golgiyaz S, Talu MF. Prediction of combustion states from flame image in a domestic coal burner. Meas. Sci. Technol. 2021.

[12] Golgiyaz S, Talu MF, Onat C. Görüntü İşleme ve Makine Öğrenmesi Yöntemleri ile Baca Gazı Sıcaklığının Tahmin Edilmesi. Eur. J. Sci. Technol. 2019;16:283-291.

[13] Akkoyun F, Ozcelik A. A Simple Approach for Controlling an Open-Source Syringe Pump. Eur. Mech. Sci. 2020;4(4):166-170. 